\title{
E. SVEIKATOS DALYVIŲ FUNKCIJŲ PASISKIRSTYMO SVARBA: DALYVIŲ VAIDMENŲ RINKINYS
}

\author{
Birutė Mikulskienė \\ Mykolo Romerio universiteto Politikos ir vadybos fakulteto \\ Vadybos institutas \\ Valakupių g. 5, LT-10101 Vilnius, Lietuva \\ Telefonas (+ 370 5) 2740610 \\ Elektroninis paštas birute.mikulskiene@mruni.eu
}

Birutė Pitrènaitè-Žilènienė

Mykolo Romerio universiteto Politikos ir vadybos fakulteto

Vadybos institutas

Valakupių g. 5, LT-10101 Vilnius, Lietuva

Telefonas (+370 5) 2740610

Elektroninis paštas birute.pitrenaite@mruni.eu

\section{Danguolè Jankauskiené}

Mykolo Romerio universiteto Politikos ir vadybos fakulteto

Politikos mokslų institutas

Valakupių g. 5, LT-10101 Vilnius, Lietuva

Telefonas (+370 5) 2740611

Pateikta 2014 m. rugsejo 9 d., parengta spausdinti 2014 m. spalio $1 \mathrm{~d}$.

doi:10.13165/SPV-14-2-7-01

\section{Santrauka}

Šio tyrimo tikslas - sukurti e. sveikatos suinteresuotuju funkciju pasiskirstymo ir bendradarbiavimo modeli ir ji patikrinti realioje sveikatos sistemoje, tai yra kaip multidisciplininiu žiniu valdymo cikle Lietuvos e. sveikatos suinteresuotieji pasiskirsto vaidmenis ir funkcijas dirbdami drauge ir kurdami e. sveikatos sistemos elementus. Minètas modelis suformuotas remiantis pagrindine prielaida: sveikatos priežiūros įstaiga ir jos darbuotojai yra pagrindiniai e. sveikatos produkto vartotojai ir savininkai, todel jie prisiima lyderio vaidmenį. Remtasi dviem valdymo teorijomis: žiniu valdymo proceso ir suinteresuotuju vaidmenu pasiskirstymo bendradarbiavimo ciklo metu. Teorinio modelio esmé yra atsakyti i klausima, 
kokiose žiniu generavimo fazèse kuris iš suinteresuotųu turètų prisiimti koordinatoriaus, formuotojo, stebètojo, igyvendintojo ar specialisto vaidmenis.

Praktiškai tikrinant modeli, empirinis tyrimas parode, kad teorinis vaidmenu pasiskirstymo modelis tik iš dalies yra realizuojamas praktikoje. Per daug funkciju vykdo Sveikatos apsaugos ministerija (SAM) ir per mažai ju tenka pačiai sveikatos priežiūros institucijai. Taip pat beveik visiškai yra ignoruojamas paciento dalyvavimas. Taip pat stebima tendencija, kad nepriklausomai nuo žiniu ciklo etapo e. sveikatos dalyviai kiekviename etape pageidautu stipraus koordinatoriaus. Jie šias funkcijas linkę perleisti SAM, taip tikedamiesi perduoti ir atsakomybę už sprendimus del finansu bei galutinio rezultato kokybę. Perdavus lyderio vaidmeni sveikatos priežiūros istaigoms (SPI), funkciju paskirstymo problemos nebütu visiškai išspręstos dèl IT įmoniu, kaip produkto kūrèjo, indèlio sureikšminimo arba kito kraštutinumo - ignoravimo ir izoliavimo. Tad IT imoniu kaip formuotojo vaidmuo galimas tik vienoje iš žiniu valdymo fazejje, o kitose fazèse jų indèlis dalinamas tarp igyvendintojo ir stebètojo.

Reikšminiai žodžiai: e. sveikata, suinteresuotieji, žiniu vadyba, vaidmenu teorija.

\section{İvadas}

E. sveikatos sistemos kūrimas reikalauja multifunkcinių gebèjimų bei kelių, neretai labai skirtingų mokslo sričių žinių. E. sveikata kuriama naudojant sveikatos mokslų, informacinių technologijų, valdymo, ekonomikos bei politikos mokslų pasiekimus. Nors atrodo jau nemažai padaryta, kad šių mokslų žinios būtų integruotos e. sveikatos sistemai kurti, vis dèlto Lietuvoje nuo $2002 \mathrm{~m}$. ne visi e. sveikatos kūrimo bandymai buvo sèkmingi. Kai kurie e. sveikatos moduliai taip ir nepradejo veikti, o véliau jiems kurti buvo ieškoma jau visai kitų sprendimų. Realizuoti naujus sprendimus buvo ieškomos kitos institucijos, neretai iš pirmo žvilgsnio nutolusios nuo sveikatos sistemos ir atrodytų neturinčios tiesioginio ryšio su sveikatos sistema, bet turinčios papildomų kompetencijų. Taip suinteresuotųjų e. sveikata ratas išaugo. Dabar, be gydytojų, IT (informacinių technologijų) specialistų, viešojo administravimo specialistų (pvz., Sveikatos apsaugos ministerijos), prie e. sveikatos projektų prisijungè konsultacinės įmonès ar Registrų centras, dalyvaujantys kuriant vaizdų apsikeitimo sistemą bei e. receptą, ir kitos institucijos.

E. sveikatos vystymas apima šias pagrindines veiklas':

- Strategijų ir vizijų kūrimas (nacionalinị kontekstą atitinkanti strategija, ją lydintys planai).

WHO-ITU. 2012. National eHealth Strategy Toolkit [interaktyvus]. [žiūreta 2014-08-10]. <http:// www.searo.who.int/entity/health_situation_trends/documents/full_version_national_ehealth_ toolkit.pdf>. 
- Investicijos (strategijos prioritetų palaikymas adekvačiais investavimo planais).

- Valdymas ir suinteresuotųjų įtrauktis (tiesioginis e. sveikatos koordinavimas - proceso kūrimas, tikslų derinimas su sveikatos prioritetais, politinio palaikymo kūrimas, pasiekimų sklaida ir bendradarbiavimas su suinteresuotaisiais.)

- Teisinis reglamentavimo ir politikos suderinamumas. Nacionalinių strategijų derinimas, teisinès bazès kūrimas, atitikties prioritetams vertinimas).

- Personalo valdymas (tinklų būrimas, kooperavimasis, e. sveikatos pasiekimų sklaida, mokymų programos).

- Standartizacija (sveikatos informacijos pasidalinimo standartizacija, suteikiant ilgalaikị informacijos kaupimą ir naudojimąsi).

- Infrastruktūra (sveikatos įstaigų geografinis susiejimas naudojantis IT infrastruktūra).

- Paslaugu pritaikomumas (pasiekiamumo valdymas, informacijos kaupimas, turinio funkcionalumas).

Daugelis išvardintų veiklų yra gan sėkmingai vykdomos (periodiškai atnaujinamos strategijos, skiriamos gan didelès finansavimo lěšos, sukurta išsami teisinè bazè e. sveikatos produktams standartizuoti, investicijos padalinamos tiek tarp infrastruktūros, tiek tarp personalo kompetencijų tobulinimo). Vis dèlto kai kurie valdymo elementai kol kas lieka problemiški, nes yra nedokumentuoti ir nereglamentuoti. Tai yra proceso turinys ir suinteresuotųjų itraukties metodai.

Šiuo tyrimu yra siekiama ištirti šias e. sveikatos Lietuvoje vystymo veiklas ir nustatyti, kokios veiklos neveikia arba turi daugiausiai problemų ir kaip jos galètų viena kitą papildyti. Tuo tikslu buvo pasirinktos dvi valdymo teorijos. Viena iš jų yra žinių valdymo procesas, kita - suinteresuotųjų vaidmenų pasiskirstymo teorija bendradarbiavimo ciklo metu. Tiketina, kad šiuos teorinius konstruktus sujungę, galètume užčiuopti e. sveikatos tobulinimo kryptis.

Tikslas - sukurti e. sveikatos suinteresuotųų funkcijų pasiskirstymo ir bendradarbiavimo modelį ir ji patikrinti realioje sistemoje, tai yra patikrinti empiriniais duomenimis, kaip Lietuvos e. sveikatos suinteresuotieji pasiskirsto vaidmenis ir funkcijas dirbdami drauge ir kurdami e. sveikatos sistemos elementus.

Metodologija grindžiama kokybiniu tyrimu taikant pusiau struktūruotą interviu metodą empiriniams duomenims surinkti. Siekiant užtikrinti kokybinio tyrimo patikimumą, respondentai buvo atrenkami užtikrinant geografinị pasiskirstymą, ịvairių lygių ir tipų institucijų atstovavimo ir užimamų pareigų ịvairovę. Atitinkamoje vaidmenų kategorijoje interviu atrinkti respondentai, einantys i̇vairias pareigas (ligoninių vyr. gydytojai, vyr. gydytojų pavaduotojai, poliklinikų direktoriai, jų patarejai, gydytojai, slaugytojai, SPI IT specialistai, SPİ IT padalinių vadovai, IT firmų vadovai ir darbuotojai, ministerijos padalinių vadovai ir kt.). 
Tyrimo originalumą nulėmé siekis ịvertinti ịvairius vaidmenis atliekančių e. sveikatos dalyvių požiūrius ị savo ir kitų veikèjų funkcijas kuriant, diegiant ir naudojant sveikatos IT sistemas. Sukurtas e. sveikatos suinteresuotųjų funkcijų pasiskirstymo modelis gan vaizdžiai gali paaiškinti neatitikimus tarp susiformavusios praktikos ir teorinès siekiamybès.

\section{E. sveikatos žinių valdymo ciklas}

Sveikatos paslaugų kokybei išlaikyti ir nuolat kelti IT siūlomi sprendimai tapo ta inovatyvia priemone, kuri pakeite požiūrị i sveikatos paslaugų kokybés turinį. Tuo pat metu atskleidè ir sudètingą egzistuojančių vadybinių praktikų suderinamumo bei žinių valdymo problemą. Dažnais e. sveikatos plètros trukdžiais yra įvardijami skirtingi personalo požiūriai ị informacijos poreikị, informacijos apsikeitimo būdus ir dažnumą ${ }^{2}$. Papildomos sumaišties atsiranda, kai ị žinių valdymo ciklus yra ịtraukiamas didesnis ratas suinteresuotųjų, kurie drauge bando ieškoti geriausių e. sveikatos sistemų realizavimo formų. Šiems procesams aiškumo gali suteikti suvokimas, kokius žinių valdymo ciklus išgyvena idejos, kol tampa suinteresuotiesiems priimtinu sprendimu.

Kiekvienas naujo sprendimo procesas išgyvena kelis žinių kaupimo, generavimo ir verbalizavimo etapus. Šie etapai darosi gan sudetingi, kai kalbama apie įtrauktį, platų suinteresuotųjų dalyvavimą. Integravus dalyvavimo politikos paradigmos turinị ${ }^{3}$ su žinių valdymo paradigma ${ }^{4}$, galima suformuoti e. sveikatos žinių valdymo ciklą (1 pav.). Ciklas apima visus žinių kūrimo ir panaudojimo etapus, dalyvaujant plačiam suinteresuotųjų ratui.

- Išankstinės žinios (angl. pre-knowledge). Suinteresuotieji dalyviai valdymo sprendimo erdveje vadovaujasi anksčiau turèta informacija, savu problemos supratimu, mąstymo būdu ir savais puoselètais prioritetais bei poreikiais.

- Asocijuotos žinios (angl. associate knowledge). Suinteresuotieji, veikdami kartu su kitais suinteresuotaisiais, bendrame tinkle išryškina ir asocijuoja turètas individualias žinias apie dabartinę būseną ị vieną visumą, akcentuodami pageidaujamų ir aktualių alternatyvų analizę.

- Naujos žinios (angl. new knowledge). Dalyviai drauge ieško visiškai naujų sprendimų, generuoja pageidaujamas alternatyvas, nagrinejja jų priimtinumą ir galimą poveikị, tikrina jų išsamumą.

King, G., et al. Boundaries and e-health implementation in health and social care. BMC Medical Informatics and Decision Making [interaktyvus]. 2012,12(100): 1-11 [žiūrèta 2014-08-10]. <http:// www.biomedcentral.com/1472-6947/12/100>.

3 Prager, K.; Nagel, U. J. Participatory decision making on agri-environmental programmes: a case study from Sachsen-Anhalt (Germany). Land Use Policy. 2008, 25: 106-115.

4 Nonaka, I.; Nishiguchi, T. Knowledge Emergence. Social, Technical, and Evolutionary Dimensions of Knowledge Creation. New York: Oxford University Press, 2001. 


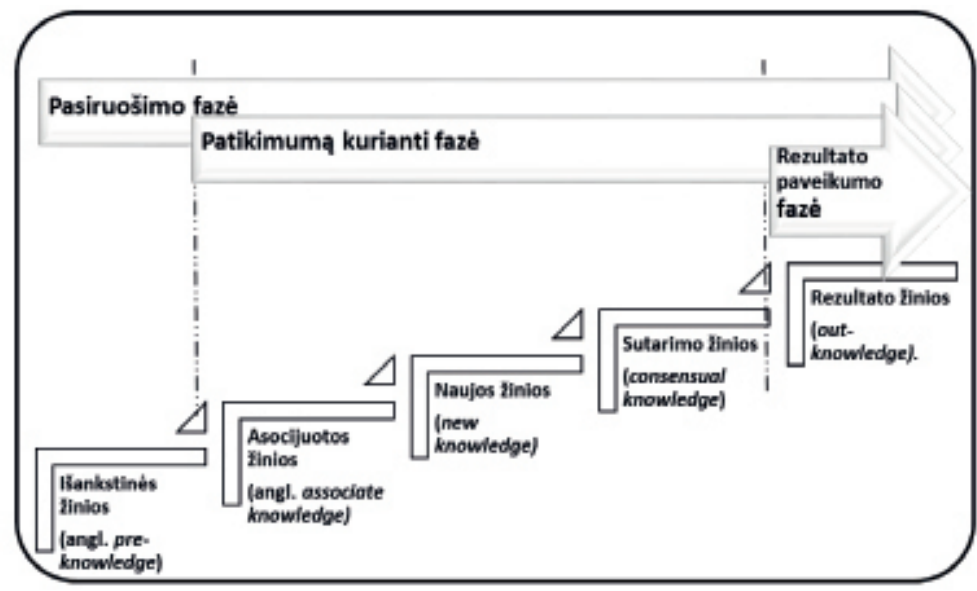

1 pav. Plataus dalyvavimo koncepcinis modelis

- Sutarimo žinios (angl. consensual knowledge). Susitarimo siekis padeda suderinti politikos dalyvių siekius tarpusavyje, susikuria erdve atsirasti bendram supratimui. Susitarimas susijęs tiek su pačios problemos suvokimu, tiek ir galimos problemos sprendimo būdais. Taip mažinama konfliktų tikimybè ir nesusikalbèjimas tolesnèse politikos formavimo fazèse.

- Rezultato žinios (angl. out-knowledge). Žinios, kurias dalyviai gauna veikdami drauge, tampa nuolatinio mokymosi proceso šaltiniu. Suinteresuotųjų mokymosi procesas lemia ateities veiksmus, sèkmę iggvendinant pasirinktą alternatyvą bei pasiruošiama kitų problemų sprendimui.

Šio žinių ciklo metu svarbus funkcinis dalyvavimas. Nors siekiama, kad visuose etapuose dalyvautų visi suinteresuotieji, tačiau jų vaidmuo, funkcijos, atsakomybè neturètų būti vienoda. Funkcijų sklaida nèra statinè, atvirkščiai, jai būdinga nuolatiné dinamika. Jei viename etape vieni suinteresuotieji prisiima inicijavimo vaidmenț, o kiti - igyvendintojo vaidmenį, tai kitame etape šiais vaidmenimis gali tekti apsikeisti. Toliau žvilgtelsime ị vaidmenų grupeje teoriją.

\section{Vaidmenų pasiskirstymo grupëje teorija}

Bendradarbiavimas grupeje ir jos rezultatyvumas priklauso nuo keturių dalykų: aiškios ir ịtraukios instrukcijos, igalinančios grupès sudèties, organizacinès struktūros paramos, ekspertinių žinių pasiekiamumo ${ }^{5}$. Kalbant apie e. sveikatos

5 Hackman, J. R.; Wageman, R.; Ruddy, T. M.; Ray, C. R. Team effectiveness in theory and practice. In: Cooper, C. and Locke, E. A. Industrial and organizational psychology: Theory and practice. Oxford, UK: Blackwell, 2000. 
problematiką, aiškių instrukcijų kuriant IT sistemas būtų nerealu tikètis, nes tai labai kūrybinis, pirmą kartą atliekamas procesas. Tuo tarpu igalinančios grupès, kuri gali pasiekti tinkamų rezultatų, sudètị ir struktūrą galima suformuoti.

Vaidmenys grupèje. Vaidmenų grupejje pasiskirstymo teorija pradejjo formuotis nuo mažų grupių tyrimų. Tirta, kaip grupeje dalyviai bendradarbiauja tarpusavyje, kokius ryšius mezga, kaip elgiasi ir kaip atlieka užduotis. Taip pat buvo gilinamasi į dalyvių socialinę-emocinę elgseną ${ }^{6},{ }^{7}$. Vèliau tyrimai peraugo i̇ sèkmingų darbo kolektyvų ir komandų tyrimus, kurie atskleidè, kad komandos sékmè ir rezultatyvumas priklauso nuo komandos narių gebejjimo pasiskirstyti vaidmenis, nuo pasireiškiančių vaidmenų pobūdžio ir jų skaičiaus. Tokių tyrimų pradininku reiktų laikyti Belbiną̨ ${ }^{8}$, . Belbinas iš pradžių išskyrè aštuonis grupès vaidmenis, vèliau sąrašą praplètė dar viena, iki devynių. Jis teigè, kad šie vaidmenys susiformuoja natūraliai ir didina komandos produktyvumą. Štai svarbiausi:

- Koordinatorius (vadovas). Tai pasitikèjimą keliantis, puikiai vadovaujantis, numatantis tikslus, pavedantis ir perskirstantis atsakomybes bei priimantis (angl. promotes) sprendimus komandos narys.

- Puoselètojas / inovatorius (angl. plant). Tai kūrybiškas, pasižymintis fantazija ir gebantis spręsti sudètingas problemas narys.

- Resursuc planuotojas (angl. resource investigator). Entuziastas ir visuomenininkas, kurio pagrindinè funkcija yra tirti galimybes bei vystyti kontaktus.

- Formuotojas (angl. shaper). Ieškantis iššūkių, dinamiškas, gerai atlaikantis laiko spaudimą, kitus skatina įveikti nesklandumus.

- Stebètojas / vertintojas (angl. monitor evaluator). Narys, kuriam pavedama nagrinèti alternatyvas ir tiksliai vertinti sprendimus, jam būdingas blaivus mąstymas ir racionalus vertinimas

- Komandos narys (angl. team worker). Besikooperuojantis, diplomatiškas ir ịsiklausantis ị kitų komandos narių nuomonę. Jis dažniausiai atsakingas už itampų komandoje mažinimą.

- Igyvendintojas (angl. implementer). Disciplinuotas, patikimas, karais konservatyvus ir efektyvus, kuriam patikima idejas paversti realybe.

- Finišuotojas (angl completer-finisher). Uolus, smalsus ir pastebintis detales, linkęs ieškoti klaidų, kad darbai būtų atlikti laiku ir be priekaištų.

- Specialistas (angl. specialist). Atsidavęs ir ịsigilinęs ị konkrečią sritį, galintis dirbti savarankiškai.

Benne, K. D.; Sheats, P. Functional roles of group members. Journal of Social Issues. 1948, 4: 41-49.

Bales, R. F. A set of categories for the analysis of small group interaction. American Sociological Review. 1950, 15: 257-263.

8 Belbin, R. M. Management Teams: Why They Succeed or Fail. Oxford: Butterworth-Heinemann,1981.

$9 \quad$ Belbin, R. M. Team Roles at Work. Oxford: Butterworth-Heinemann, 1993. 
Vaidmenų pasiskirstymo pusiausvyra. Viena svarbiausių Belbino teorijos pridètinių verčių buvo pagrịsta vèlesniais tyrimais, kad egzistuoja tarpusavio priklausomybe tarp vaidmenų komandoje pasiskirstymo pusiausvyros ir komandos darbingumo / rezultatyvumo ${ }^{10}$. Vaidmenų pusiausvyra komandoje tampa svarbiu komandos suderinamumo uždaviniu. Belbinas savo tyrimus apibendrino, padarydamas išvadą, kad šešių narių komanda yra optimali dirbant su kompleksinèmis problemomis. Vadinasi, jei pripažistame 9 galimus vaidmenis, tai keli komandos nariai gali realizuoti daugiau nei vieną vaidmeni. Dažniausiai kiekvienas komandos narys atstovauja kuriam nors konkrečiam vaidmeniui, dominuoja vienas iš vaidmenų, tačiau antrasis vaidmuo taip pat gali pasireikšti gan reikšmingai. Kadangi vadybai svarbu matuoti vaidmenų pasiskirstymo balansą, Paringtonas ir Harris pasiūlè matuoti grupés suderinamumo indeksą (angl. Team Balance Indices $)^{11}$, kuris leido empiriškai vertinti, kaip keičiasi grupès rezultatyvumas, keičiantis vaidmenų pasireiškimo laipsniui. Taip buvo nustatyta, pavyzdžiui, kad stiprus koordinatorius dažnai mažina grupès rezultatyvumą. Tai susiję su kitų komandos narių funkcijų raiškos slopinimu. Dažniausiai slopinama iniciatyva, kūrybiškumas ir kuriama didesnè priklausomybė nuo centralizuoto sprendimo. Komandos, kuriose nèra inovatoriaus, dažnai turi problemų pradèti naujus projektus, vystyti naujas idejjas. Tačiau kai inovatorių yra per daug, idejjos ima konkuruoti ir tampa sudètinga išsirinkti vieną, ties kuria reiktų dirti. Taip veiklos véluoja.

Grupių dinamika. Darbo grupèse rezultatas, be abejo, yra nulemiamas ir komandos vystymosi stadijos. Perimti konkrečias funkcijas, pasiskirstyti atitinkamus vaidmenis vienas kitą papildant reikia laiko. Literatūroje galime rasti penkių lygių komandos vystymosi modeli ${ }^{12}$, kuris susieja grupès rezultatyvumą sprendimų prièmimo metu. Skiriami šie lygiai: užduočių akcentavimas, procesas, grupès struktūra, grupès dinamika ir grupès pasitikejimas. Šis modelis, nors ir nenurodo tiesioginių priklausomybių prognozuojant grupés rezultatyvumą, tačiau akcentuoja galimų nesèkmių sritis. Tyrimais yra ịrodyta, kad geresnių rezultatų pasiekia tos komandos, kurios yra penktoje vystymosi stadijoje (komandų nariai pasitiki vienas kitu ir savo lyderiais), yra perèję dinamikos fazę (nariai ittraukiami ir dalyvauja bei prisiima įsipareigojimus veikti). Pasirodo, tokios komandos yra kūrybiškesnès ir efektyviau pasinaudoja savo specifinèmis žiniomis, t. y. geriau pasinaudoja specialistų grupeje žiniomis ${ }^{13}$.

10 Senior, B. Team roles and team performance: Is there 'really' a link? Journal of Occupational and Organizational Psychology. 1997, 70(3): 241-258.

11 Partington, D.; Harris, H. Team balance and team performance: an empirical study. The Journal of Management Development. 1999, 18(8): 694-701.

12 McFadzean, E. Developing and supporting creative problem-solving teams: Part 1 - a conceptual model. Management Decision. 2002, 40(5/6): 46--476.

13 Chong, E. Role Balance and Team Development: A Study of Team Role Characteristics Underlying High and Low Performing Teams. Journal of Behavioral and Applied Management, 2007, May 1. 
E. sveikata ir vaidmenų grupëje teorija. Belbino vaidmenų pasiskirstymo grupejje teorijos pritaikymas e. sveikatos reikalų sprendimui ir suinteresuotųjų veikimo drauge strategijoms kurti nèra jau toks savaime suprantamas dalykas. E. sveikatos sistemos nuolat reikalauja naujų, novatoriškų sprendimų, o tai verčia burti vis naujas komandas, ieškoti vis naujų sąveikos būdų, taip lyg ir nebelieka vienos iš pagrindinių Belbino teorijai pasireikšti reikalingų prielaidų: komandų formavimosi laiko ir vaidmenų pasiskirstymo pusiausvyros nusistovejjimo. Vis dèlto negalima ignoruoti to fakto, kad suinteresuotieji gali pasiekti visoms pusėms priimtinų rezultatų ir produktyvumo veikiant drauge tik tuomet, kai visos funkcijos yra vykdomos, tai yra kai kuriamam produktui yra vartotojas, yra koordinatorius, atsakingas už visus kūrimo etapus, yra savininkas (formuotojas), kuris prisiima atsakomybę už produkto kūrimo ir jo tolesnès plètros sąlygas, yra specialistas, suteikiantis reikiamų ekspertinių žinių ir pan. Tad taikant šią teoriją e. sveikatos bendradarbiavimo klausimams spręsti, reikia turèti omenyje ir kitas rezultatyvumo sąlygas, tokias kaip organizacinès struktūros palaikymą, gairių ir instrukcijų rengimą bei ekspertinių žinių pasiekiamumą.

\section{Tyrimo metodologija}

Tyrimo metodologija yra pagrịsta teorinio konstrukto kūrimu ir jo tikrinimu empiriniais metodais.

Teorinis tyrimas. Teoriniam tyrimo konstruktui sukurti buvo pasiremta dvimačiu statiniu modeliu. Vienas matmuo atitinka suinteresuotųjų vaidmenų raišką, pasiremiant suinteresuotųjų valdymo teorija, nusakančia darbo grupèse patirtị ${ }^{14}$. Antrasis matmuo yra žinių valdymo etapai. Teoriškai suliejant šias teorijas buvo ieškomas atsakymas ị klausimą, kaip keičiasi suinteresuotųjų vaidmenys keičiantis žinių valdymo etapams. İrodymus apie susiklosčiusias vaidmenų pasiskirstymo praktikas pasaulyje gan išsamiai yra atskleidusi Pasaulio sveikatos organizacija (PSO). Jos suformuluoti sveikatos priežiūros principai leidžia gan nesunkiai rekonstruoti hipotetinius vaidmenų pokyčius, vadovaujantis pagrindine prielaida - sveikatos priežiūros ịstaiga ir jos darbuotojai yra pagrindiniai e. sveikatos produkto vartotojai ir savininkai, todèl jie prisiima lyderio vaidmeni. Kad teorinis tyrimo konstruktas būtų lengviau suvokiamas, buvo ignoruojamas tas faktas, kad kiekviena iš suinteresuotųjų pusių gali prisiimti daugiau nei vieną vaidmenị, tad konstruktas atitinka tik pagrindinị hipotetinị suinteresuotųjų vaidmenị vieno žinių valdymo ciklo metu.

Empirinis tyrimas. Tyrimas atliktas taikant pusiau struktūrizuoto interviu metodiką. Interviu atlikti 2013 m. gegužę-liepą ir rugsejji-gruodị. Kokybiniame tyrime dalyvavo 59 respondentai.

14 Belbin, R. M., supra note 9. 
Tyrimo įrankis. Kokybinio tyrimo strategija ir tyrimo įrankiai suformuoti taip, kad leistų susipažinti su e. sveikatos dalyvių požiūriu, patirtimi ir vertinimais kuriant, diegiant ir naudojant e. sveikatos informacines sistemas. Klausimyną sudare penki diagnostiniai blokai: e. sveikatos elementai, bendradarbiavimas, reguliavimas, vaidmuo e. sveikatos sistemoje, problemos. Šiame straipsnyje analizuojami interviu duomenys, gauti respondentams pasisakant vaidmenų e. sveikatos sistemoje klausimais. Respondentams dèl vaidmenų buvo pateikti keli pagrindiniai klausimai: SAM vaidmuo ir įtaka e. sveikatos projektu sèkmei; respondento institucijos vaidmuo e. sveikatos sistemos integralumui; IT firmos (diegejo) vaidmuo e. sveikatos projektų sèkmei; kitų e. sveikatos dalyvių vaidmuo. Atviri klausimai leido respondentams išsakyti savo požiūrị i savo ir kitų e. sveikatos dalyvių esamus ir / ar turinčius būti atliekamus vaidmenis ịvairiuose nacionalinès e. sveikatos sistemos kūrimo procesuose.

Respondentu atranka. Siekiant užtikrinti kokybinio tyrimo patikimumą, respondentai buvo atrenkami užtikrinant geografinị pasiskirstymą, ịvairių lygių ir tipų institucijų atstovavimo ir užimamų pareigų ịvairovę:

- geografinis respondentų pasiskirstymas. Interviu dalyvavo respondentai, atstovaujantys sveikatos sistemos organizacijoms iš 10 Lietuvos miestų (Vilnius, Kaunas, Klaipėda, Šiauliai, Panevėžys, Tauragė, Utena, Kupiškis, Rokiškis, Pasvalys);

- pasiskirstymas pagal organizacijos tipą. Respondentai atstovavo 8 tipu organizacijoms (ligoniné, poliklinika ir priminès sveikatos priežiūros centras, privati SPĮ, universitetinès klinikos ir klinikų padalinys (toliau kliniku ligoninè), ministerija, ministerijai pavaldi institucija, IT firma (1 lentelè). Be to, atrenkant respondentus pagal atstovaujamas organizacijas, siekta apklausti ir labiausiai pažengusiųjų e. sveikatos srityje (Centro poliklinika Vilniuje, Vilniaus universiteto Santariškių klinikos), ir iš tų SPİ, kurios įdiegę tik centralizuotas IS (rajonų SPĮ);

- respondentų pasiskirstymas pagal vaidmenis ir pareigas. Tiriamas įvairius vaidmenis atliekančių e. sveikatos dalyvių požiūris ị savo ir kitų veikejų funkcijas kuriant, diegiant ir naudojant sveikatos IT sistemas (2 lentelè). Atitinkamoje vaidmenų kategorijoje interviu atrinkti respondentai, einantys ịvairias pareigas (ligonių direktoriai, vyr. gydytojai, jų pavaduotojai, poliklinikų direktoriai, jų patarejai, gydytojai, slaugytojai, SPI IT specialistai, SPİ IT padalinių vadovai, IT firmų vadovai ir darbuotojai, ministerijos padalinių vadovai ir kt.). 
1 lentelè. Respondentų sąrašas pagal organizacijas

\begin{tabular}{|l|c|}
\hline \multicolumn{1}{|c|}{ SPI tipas / organizacija } & $\begin{array}{c}\text { Respondentų } \\
\text { skaičius }\end{array}$ \\
\hline SAM ir kt. reguliuojančios institucijos & 4 \\
\hline Klinikos, klinikų ligoniné & 5 \\
\hline Ligoniné & 18 \\
\hline Poliklinika, PSPC & 16 \\
\hline Privati SPI & 10 \\
\hline IT firma, konsultacine firma & 6 \\
\hline \multicolumn{1}{|c|}{ Iš viso: } & 59 \\
\hline
\end{tabular}

2 lentelè. Respondentų sąrašas pagal vaidmenis

\begin{tabular}{|l|l|c|}
\hline \multicolumn{1}{|c|}{$\begin{array}{c}\text { Respondentų } \\
\text { kategorija }\end{array}$} & \multicolumn{1}{|c|}{ Respondentų pareigos } & $\begin{array}{c}\text { Respondentų } \\
\text { skaičius }\end{array}$ \\
\hline IT (išoriniai) & $\begin{array}{l}\text { Direktorius, e. sveikatos projektų koordinato- } \\
\text { rius, priežiūros direktorius }\end{array}$ & 6 \\
\hline Medicinos personalas & Gydytojas, vyr. slaugytojas, slaugytojas & 11 \\
\hline $\begin{array}{l}\text { SAM ir kt. reguliuo- } \\
\text { jančios institucijos }\end{array}$ & Skyriaus vedejas, vyr. specialistas \\
\hline SPI specialistai & $\begin{array}{l}\text { IT padalinio vadovas, IT specialistas, e. svei- } \\
\text { katos projekto koordinatorius, finansininkas, } \\
\text { ekonomistas, laboratorijos vedejas, vidaus au- } \\
\text { dito tarnybos vadovas, vyr. slaugos administ- } \\
\text { ratorius }\end{array}$ & 20 \\
\hline SPI vadovai & Direktorius, vyr. gydytojas, jo pavaduotojas & 18 \\
\hline \multicolumn{1}{|c|}{ Iš viso: } & \multicolumn{2}{|c}{} \\
\hline
\end{tabular}

Interviu atlikimas. Interviu buvo atliekami užtikrinant respondentų anonimiškumą tam, kad būtų gauti atviri atsakymai ị interviu klausimus. Todèl apdorojant interviu duomenis kiekvienam respondentui suteiktas unikalus kodas. Kodas suteikia informaciją apie respondento atstovaujamą instituciją ir jo einamas pareigas.

Kiekvienas interviu buvo organizuotas respondento darbo vietoje, pokalbius ịrašant ị diktofoną. Pokalbio metu taip pat buvo užsirašomos pagrindinès respondentų mintys ir idejjos, kas vèliau tyrẻjams leido geriau struktūrizuoti gautus duomenis. Kiekviename interviu dalyvavo bent 2 tyrèjai, užtikrinant, kad neliks neatsakytų svarbių klausimų ar nebus atkreiptas dėmesys ị svarbias detales. 
Interviu trukmè - ne mažiau kaip 1 val. Pusiau struktūruoto interviu klausimai suformuluoti ir užduodami taip, kad paliktų erdvès respondentui išryškinti jam svarbiausius e. sveikatos sistemos kūrimo aspektus.

Interviu duomenu analize. Visi interviu įrašai buvo transkribuoti. Naudojant kokybinių duomenų analizès programą NVivo, respondentų pasisakymai buvo grupuojami ị kategorijas ir subkategorijas įvairiais pjūviais. Interviu duomenys, susiję su e. sveikatos dalyvių vaidmenimis, buvo kategorizuojami taip, kad tyrëjams suteiktų informacijos: kas pasakè apie vaidmenį; apie kieno vaidmeni kalbèta, kokiam e. sveikatos sistemos kūrimo procesui vaidmuo priskiriamas. Būtent tokiais pjūviais šiame straipsnyje pateikiami apibendrinti interviu rezultatai apie e. sveikatos dalyvių vaidmenis.

\section{E. sveikatos suinteresuotųjų vaidmenų pasireiškimo hipotetinis modelis}

- Dèl poreikio ittraukti suinteresuotuosius jau nebediskutuojama. Pasaulio sveikatos organizacija teigia, kad ịtraukus ị bendras veiklas suinteresuotuosius ir plačią visuomenę, veikimas drauge sukuria ilgalaikio bendradarbiavimo ryšius, susikuria mokymosi procesas. O kartu tai leidžia numatyti, kokių e. sveikatos paslaugu gali prireikti ateityje $\mathrm{e}^{15}$. Pasaulio sveikatos organizacija gan vienareikšmiškai apibrěžia, kokių vaidmenų iš kiekvienos interesų grupès galima tikètis e. sveikatos sistemos kūrimo metu:

- Sveikatos paslaugų teikéjams siekiama suteikti vadovavimą, krypties nustatymą, resursų valdymą, patikima spręsti projektinių veiklų nesklandumus (spręsti iškilusias problemas, konfliktus).

- Geriausia, jei sveikatos apsaugos ministerijoms teks atsakomybė ne tik užtikrinti, kad pacientų sveikatos paslaugų poreikiai būtų pasiekti, bet taip pat ir planuoti e. sveikatos sistemų plètrą ateityje. Taip pat yra rekomenduotina atskirti finansuotojo vaidmenį nuo koordinuotojo. Ir tai jau daroma Lietuvoje.

- Už komunikacijas ir IT plètrą atsakingų ministerijų funkcija yra suteikti turimą kompetenciją ir resursus, integruojant sveikatos paslaugas ị elektronines sistemas.

- Ekspertams pavedama teikti plètros ir vystymo krypčių rekomendacijas, padèti planuoti, prognozuoti būsimus poreikius, nukreipti suinteresuotuosius, atlikti tarpinių ir galutinių produktų periodines patikras ir analizes.

- Iš visuomenès ar pacientų yra laukiama labiau grịžtamojo ryšio vertinant jau galutinį produktą nei tiesioginio dalyvavimo prie užduočių formavimo.

Apibendrinant ryškejja pagrindinès e. sveikatos produktų kūrimo tendencijos - kuriant e. sveikatos sistemas lyderio vaidmeni rekomenduojama suteikti

15 WHO-ITU. 2012. National eHealth Strategy Toolkit, supra note 1. 
pačioms sveikatos įstaigoms. Tuo tarpu ministerijoms rekomenduojama pavesti būti atsakingoms dirbti su suinteresuotaisiais ir net rūpintis, kad suinteresuotieji taptų motyvuoti prisiimti jiems visai naujus vaidmenis. Iš IT įmonių tikimasi aktyvumo dalyvaujant ir taikant savo sukauptą verslo ir IT patirtį, vengiant bet kokios didesnès jų lyderystès.

Taigi, kuriant hipotetinị suinteresuotųjų vaidmenų pasiskirstymo modelį svarbu nustatyti visą suinteresuotųjų sąrašą ir iš jų suformuoti svarbiausias suinteresuotujjų grupes. Galima skirti dvi pagrindines tokias grupes:

Sveikatos sektoriaus suinteresuotieji:

- Sveikatos specialistų asociacijos.

- Gydymo įstaigų asociacijos.

- Akademinių ir mokslinių institucijų atstovai.

- Sveikatos draudimo paslaugų ístaigos.

- Pacientų organizacijos.

- Visuomenè.

- Itvairių pavaldumo lygių (nacionalinès, regioninès, savivaldos) valdžios sveikatos priežiūros institucijos.

- Privačios sveikatos priežiūros įstaigos, tarp jų ir nevyriausybinės ar labdaros organizacijos.

- Sveikatos IT produktų įmonès (nacionalinès ar tarptautinės).

2. Žiniasklaida (nacionalinè, regioniné, specializuota).

3. Kiti, netiesiogiai su sveikatos sektoriumi susiję suinteresuotieji:

- Viešasis administravimas (registracinès sistemos, statistikos departamentas, susisiekimo ministerija).

- Privatus IT sektorius (infrastruktūra ir paslaugos).

- Ugdymo, socialinių reikalų ir bendruomenių paslaugų sektorius.

- Saugumas ir civiliné sauga.

- Inovacijos, pramoné, mokslinio tyrimo sektorius.

- Biudžetas ir finansai.

- Tarptautinès organizacijos (pvz., Europos Komisija).

E. sveikatos sektoriaus reikalams spręsti yra gausus būrys suinteresuotųjų, kurių indèlis racionalizuojasi per bendrą veikimą grupejje. Pritaikius vaidmenų teoriją e. sveikatos suinteresuotųjų bendradarbiavimo grupeje, galime nustatyti, kurie vaidmenys realizuojami, o kurių yra vengiama, kurie savo potencialo neišnaudoja arba savo funkcijomis piktnaudžiauja.

Tolesniam modeliavimui suformuotos šešios suinteresuotųjų grupès:

- Sveikatos apsaugos ministerija ir kitos su sveikatos apsaugos reguliavimu susijusios viešojo administravimo institucijos. Tai Sveikatos apsaugos ministerija, Valstybinè ligonių kasa, Registrų centras.

- IT įmone. Programavimo ar konsultacines paslaugas teikianti privataus kapitalo įmoné. 
- SPt ir ju vadovai. Sveikatos priežiūros įstaigos, kurioms atstovauja jų vadovai. Tai suinteresuotasis, kurio sprendimai dažniausiai yra strateginès reikšmés.

- Medicinos personalas. Tai gydytojai ir slaugytojai, kurie tiesiogiai teikia medicinos paslaugas.

- SPI specialistai. Tai sveikatos priežiūros įstaigų specialistai, kurie patys tiesiogiai nedalyvauja teikiant medicinos paslaugas - IT specialistai, finansininkai, vidutinès grandies vadybininkai.

- Pacientai. Tai medicinos paslaugų vartotojai.

Šių šešių grupių užtenka atskleisti svarbiausias funkcijų pasidalinimo tendencijas. Tiesa, reikia turèti omenyje, kad kiekviena iš suinteresuotųjų pusių gali prisiimti daugiau nei vieną funkciją, vis dèlto modelis apima būdingiausių funkcijų pasiskirstymą. Toliau modelyje kol kas neaptarsime pacientų vaidmens, kuris yra beveik nepriklausantis nuo žinių generavimo ciklo. Pagal Sveikatos pasaulio organizacijos rekomendacijas, pacientas yra arba užsakovas, arba stebètojas, arba vertintojas. Lietuvoje paciento vaidmuo dar mažiau matomas.

Kiekvienas e. sveikatos sprendimas pereina tas pačias žinių valdymo fazes. Tiek, tarkime, kuriant e. sveikatos strategiją, tiek kuriant konkrečią e. sveikatos paslaugą, procesas nuo idejos poreikio iki jos realizavimo pereina tas pačias fazes: išankstinių žinių surinkimą, asocijuotų žinių susisteminimą, naujų žinių kūrimą ir t. t. Suprantama, kad kiekvienos fazès trukmès gali skirtis, tačiau šiame modelyje laikysime, kad fazès yra vienodos trukmès.

Toliau modelis formuojamas remiantis pagrindine prielaida: sveikatos priežiūros įstaiga ir jos darbuotojai yra pagrindiniai e. sveikatos produkto vartotojai ir savininkai, todèl jie prisiima lyderio vaidmenị. Tai reiškia, kad tos funkcijos, kurios apima veiklų koordinavimą, idejų formavimą arba reikalauja specifinių medicinos žinių, yra padalinamos tarp SPİ darbuotojų (vadovų, medicinos personalo arba kitų specialistų). Teorinis suinteresuotųjų vaidmenų pasiskirstymo hipotetinis realizavimas pavaizduotas 2 pav.

Taigi, išankstinių žinių kaupimo fazeje svarbu surinkti visas šiuo metu egzistuojančias žinias tiek apie esamas technologijas, tiek apie suinteresuotuosius, tiek apie galimus besikeičiančius poreikius. Idealiu atveju tiketina, kad SAM gali tapti šio etapo koordinatoriumi, nes dar ne visi suinteresuotieji gali būti žinomi arba supratę savo vaidmenị. Patị e. sveikatos detalų poreikị žinioms gali išmanyti SPI vadovai, jaučiantys, kad organizacijai reikalingi konkretūs elektroniniai sprendimai. Tai realizuojasi, jei SPI vadovai igyja formuotojo vaidmenị. Medicinos personalas, išmanydamas sveikatos technologijas ir tiesiogiai bendraujantis su pacientu, turi sukaupęs specialistui būdingų žinių. SPI specialistai ruošiasi igyvendinti e. sprendimus. Tuo tarpu IT įmonè gali būti stebėtoja, kuri ruošiasi būsimus sprendimus realizuoti. Tuo pat metu IT įmonè, gal būti vertinama ir kaip specialistai, kurie teikia savo ekspertinę nuomonę apie esamus IT sprendimus. 
Asocijuotų žinių kūrimo fazèje yra analizuojama sukaupta informacija, ji personifikuojama, adaptuojama esamai situacijai, ja dalijamasi, kol sukauptos žinios yra interpretuojamos vienodai visų suinteresuotųjų. Koordinatoriaus vaidmenį išsaugo SAM, taip lyg ir pasidalindama savo vadovavimo resursais, tuo tarpu formuotoju šioje fazèje tampa medicinos personalas, taip tarsi pranešdamas, kad jo poreikis turi būti išgirstas, o SPI vadovai dalyvauja dalindamiesi vadybinėmis žiniomis kaip specialistai. Visų kitų grupių funkcijos išlieka nepakitusios.

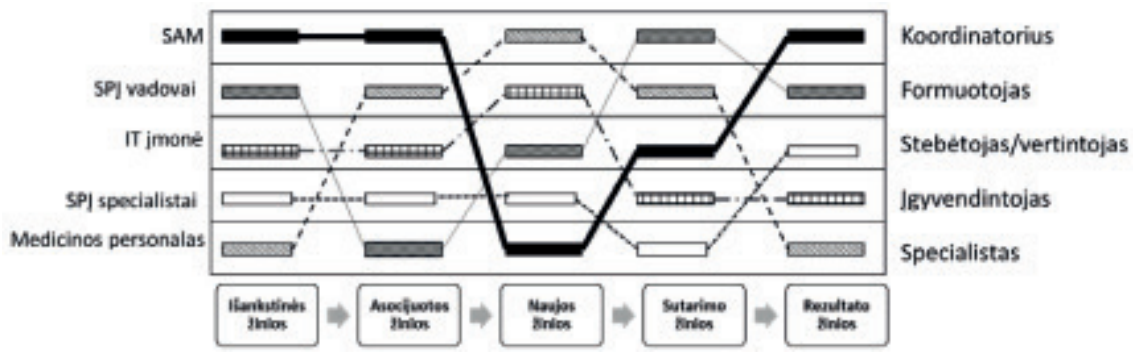

2 pav. Teorinio suinteresuotųjų vaidmenų pasiskirstymo hipotetinis realizavimas: vaidmenų pasiskirstymas tarp e. sveikatos suinteresuotųjų žinių valdymo ciklų metu (sukurta sujungus Belbino vaidmenų grupeje teoriją ${ }^{16}$ su Pasaulio sveikatos organizacijos rekomendacijomis ${ }^{17}$ )

Naujų žinių kūrimo etape idejų formuotoju reikètų laikyti IT įmonę, kuri kartu su SPİ specialistais (šiuo atveju būsimais sprendimų ịgyvendintojais) ieškotų sprendimų ir jų formų medicinos personalo suformuotiems tikslams pasiekti. Tad šioje fazeje medicinos personalui turètų tekti koordinatoriaus vaidmuo. SAM taip pat turi savo reikšmingą vaidmeni - dalinasi savo specifinèmis politiką atspindinčiomis ir viešojo valdymo specifiką atitinkančiomis žiniomis. Ši kartą vadovams tenka gal ir pasyvus, bet projekto kokybei būtinas stebėtojo vertintojo vaidmuo.

Sutarimo žinios susijusios su derybomis tarp skirtingiems požiūriams atstovaujančių interesų dèl po analizės einančių pasirinkimų, alternatyvų atsisakymo ir konkrečios alternatyvos pasirinkimo. Šioje fazejje geriausia, kai SAM pasirenka vertintojo funkcijas ir nedarydama išorinio ar politinio sprendimo sudaro erdvę suinteresuotiesiems siekti susitarimo. Tuo tarpu medicinos personalas yra atsakingas už procesų koordinavimą

Rezultato žinių fazèje SAM gali vèl prisiimti koordinatoriaus vaidmenị, SPI vadovai tampa atsakingi už formuotojo vaidmenị. Iš tiesų, šiame etape tarsi grịž-

\footnotetext{
16 Belbin, R. M., supra note 9.

17 WHO-ITU. 2012. National eHealth Strategy Toolkit, supra note 1.
} 
tama ì pirmosios fazès vaidmenų būseną, išskyrus SPI specialistus, kurie dabar jau atsakingi už kuriamo produkto kokybę, todẻl jiems suteikiama vertintojo funkcija.

Kitame skyrelyje sukurtas hipotetinis modelis buvo patikrintas empiriniu tyrimu.

\section{Apibendrinta tyrimo analizè: e. sveikatos dalyvių požiūris ị savo ir kitų dalyvių vaidmenis}

Analizuojant interviu duomenis, būdingos citatos buvo atrinktos taip, kad būtų galima diagnozuoti, kaip kiekvienos e. sveikatos dalyvių grupés atstovai vertina savo ir kitos veikejuc grupès vaidmenis planuojant, kuriant ir diegiant IS. Apibendrinti analizès duomenys straipsnyje pateikiami pagal išorinių IT firmų, medicinos personalo, pacientų, SAM ir kitų reguliuojančių institucijų, SPI specialistu ir SPI vadovų vaidmenis - t. y. kokius vaidmenis jiems priskiria kiti e. sveikatos dalyviai ir jie patys bei lyginant su teoriniu vaidmenų pasiskirstymo žinių valdymo ciklų metu modeliu.

Pateikiant interviu citatas nurodomas respondento kodas, kur skaičius reiškia respondento Nr., pirmoji kodo raidè - atstovaujamą organizaciją (P - poliklinika arba priminès priežiūros centras, L - ligoninè, $\mathrm{R}$ - SAM ar kita reguliuojanti institucija, IT - IT ar konsultaciné firma, Pr - privati SPI), antroji kodo raidè - respondento einamas pareigas (A - administracijos darbuotojas, įskaitant SPI vadovus, IT - informacinių technologijų, kompiuterinių sistemų padalinių darbuotojas ar vadovas, $\mathrm{M}$ - medicinos personalas - gydytojas, slaugytojas, VT - valstybès tarnautojas, P - e. sveikatos projekto vadovas, koordinatorius, D - IT firmos direktorius).

SAM vaidmuo. Pagal teorinị vaidmenų pasiskirstymo žinių valdymo ciklų metu hipotetinị modelį, SAM turètų daugiausia realizuoti koordinatoriaus funkcijas, išskyrus, kai kuriamos naujos žinios (specialisto vaidmuo) ir formuojamos sutarimo žinios (kai veikia kaip vertintojas).

Visų grupių respondentai pripažįsta svarbų SAM vaidmenị ir didelę jos ittaką e. sveikatos projektų sèkmei. Anot SPI vadovų, "galima projektus vykdyti labai gerai, tačiau jeigu nebus sureguliuota teisine bazé, efektyvumas bus ribotas" (22P-A). Kalbant apie visus e. sveikatos sistemos kūrimo etapus, o ypač planavimą, akcentuojamas vadovavimo ir koordinavimo būtinumas: „kažkas turi jaustis šeimininku. Ir jeigu e. sveikata yra tarsi pereinamoji raudonoji vèliava, <...> tai tada aš su savo šviesiomis ir patraukliomis idejomis neužbaigsiu jokiu projektü" (42-PA). Būtent šie vaidmenys siejami su ministerija: „SAM turi koordinuoti ir lemti e. sveikatą. Sistemų integravimo prasme jos vaidmuo labai svarbus“ (24-L-IT).

Tačiau respondentai įžvelgia koordinavimo spragų, ypač jo buvo pasigesta pirmajame nacionalinės e. sveikatos sistemos kūrimo etape: „reikalingas koor- 
dinavimas. Kai valstybès institucija kuria kokia nors programa (kaip buvo VLK SveiDra atveju), ji turètu susirinkti informacija, kokia institucija ka turi, o tik tada pradeti kurti sistema" (23-L-A). Koordinavimo stoką respondentai izžvelgia kaip vieną iš pagrindinių priežasčių, kad buvo sukurta daug ịvairių vidinių (organizacijos lygio) IS, kurias dabar sudetinga susieti ị vieną integralią sistemą. Vis dèlto ir antrajame nacionalinès e. sveikatos sistemos kūrimo etape respondentai iš SPI (ypač tų, kurios turi mažiau patirties kuriant e. sveikatos produktus) pasigenda informacijos, paramos ir glaudesnio ryšio su ministerijos specialistais: „žinokit, mes, vykdydami projektą, su SAM praktiškai neturim kažkokio artimesnio ryšio, ir jie mums nèra nei pataréjai, nei koordinatoriai" (26-L-IT). Vadinasi, kaip ir numato teorinis modelis, kai kurie e. sveikatos veikejai tikisi iš ministerijos ne tik koordinatoriaus, bet ir specialisto vaidmens atlikimo. Kita vertus, e. sveikatos kūrimu suinteresuoti respondentai suvokia, kad už e. sveikatos sistemos kūrimą atsakingiems ministerijos darbuotojams reikalingas politinis palaikymas bei atitinkami žmonių ištekliai: „reikètų daugiau tokiu žmoniu, iš ministerijos, ir patyrusiu, kad darbo grupe dirbtu centralizuotai. Man neatrodo, kad kol kas kam nors e. sveikata įdomi. Pažiūrékit ị ministerijos lankstinuką. Analize lyg ir vyksta ... kažkas, bet nieko aiškaus. Paieškokim pagal e. sveikatos raktinị žodị..." (11-PA). Politinès galios ir valios trūkumą ministerijoje įžvelgè ir kai kurie išorinių IT įmonių vadovai, pastebejję nedarną tarp e. sveikatą reguliuojančių institucijų: „visos yra nuolatiniame konflikte (SAM, Registrų centas, VLK ir kiti). SAM pavaldžios institucijos stovi ịtakos sferoj sprendimu priemime gerokai aukščiau negu pati ministerija" (60-IT-D).

SPİ vadovų vaidmuo. Skirtinguose žinių vadybos etapuose SPĮ vadovai pagal teorinị modelị turètų atlikti vis skirtingus vaidmenis. Išankstinių žinių etape jie turètų būti formuotojais, asocijuojant žinias - šis vaidmuo pereina medicinos personalui, o vadovai tampa savo srities specialistais. Kuriant naujas žinias, pastarieji turètų tapti stebėtojais ir vertintojais, o ieškant sutarimo tarp suinteresuotųjų - koordinuoti ši procesą. Sugeneravus žinių rezultatą, SPİ vadovams teorija numato formuotojo vaidmenį dèl būtinybès priimti IS kūrimo ir diegimo sprendimus.

Analizuojant respondentų požiūrius ị SPĮ vadovų vaidmenis stebimi nuomonių ir patirčių skirtumai, priklausantys nuo vadovaujančiųjų asmenų nusiteikimo ir aktyvumo kuriant IS. Kai kurie iš vadovų e. sveikatos elementus vertina kaip svarbią SPI veiklos sriti, kuriai būtina skirti pakankamai dèmesio: „sistema - lyg ir vadovo rüpestis. Nuolat gaunam nurodymu, ka turim daryti kitaip“ (11-P-A). Kiti vadovai imasi iniciatyvos ir įsipareigoja patys valdyti e. sveikatos kūrimo SPI procesus: „skirtumas tarp manęs (SPI vadovybès - aut. pastaba) ir gydytoju todèl, kad aš „užvedu“ iniciatyva“" (8-L-A). Tuo tarpu kitu grupių respondentai yra susidūrę su SPĮ vadovų nusišalinimu nuo sistemų kūrimo veiklos, t. y. šių respondentų patirtis rodo, kad vadovai atlieka tik pasyvaus stebètojo 
vaidmenį: „vadovams šitos sistemos neįdomios. Jie nori ja turèti, bet kas ten bus, kaip ten ka reikés kurti - nerūpi“ (36-IT-D). Respondentai akcentuoja būtinybę vadovams atlikti aktyvius vaidmenis: „tas tylus vadovybes palaikymas - jis nepakankamas, turi büti aktyvus, turi büti domèjimasis, turi būti vis tik... na, toks kolegialus" (26-L-IT). Jei vadovybė atitolusi ir neatlieka reikiamuose etapuose koordinuojančio vaidmens, e. sveikatos sprendimai gali būti realizuoti ne tokie, kokių reikia SPİ kaip organizacijai, o geriausiai tinkantys tam tikroms grupėms. Todèl IS gali būti nesubalansuota organizacijai tinkamiausiu būdu.

Išorinių IT ịmonių vaidmuo. Teoriškai, išankstinių ir asocijuotų žinių valdymo etapų metu IT įmonès turètų atlikti stebėtojų vaidmenį, nes e. sveikatos sistemos esama situacija žinoma ir nauji poreikiai numatomi vidinių sveikatos apsaugos sistemos dalyvių. Tačiau naujų žinių kūrimo etape IT įmonès tampa formuotojais, nes jie geriausiai žino, kaip (ir ar i̇manoma) tinkamai įvykdyti norimos sukurti IS sistemos reikalavimus. Kitiems e. sveikatos dalyviams ieškant sutarimo (sutarimo žinių etapas) ir sutarus dèl IS elementų (rezultato žinių etapas), IT įmone atlieka iggyvendintojo vaidmenį realizuodama užsakovų poreikius.

Dèl išorinių IT įmonių vaidmens išsiskyrẻ požiūriai tarp to, kaip savo vaidmenị suvokia pačios IT įmonès, ir kokius vaidmenis jiems numato ir / ar kokią patirtį su jais turi kiti e. sveikatos suinteresuotieji. IT imonių respondentai sau numato įvairias funkcijas. Jų nuomone, IT firmos atlieka formuotojo vaidmenị, nes „čia jau yra šventa taisykle - niekada vartotojas iki galo nežino, ko jis nori“ (36-IT-D). Vis dèlto dažniausiai akcentuojamas igyvendintojo vaidmuo: „mūsu strategija ir yra tokia: jei yra poreikis - mes produkta kuriam" (37-IT-D). Taip pat interviu metu nuskambèjo neutralumo pozicijos požiūriai, kai neprisiimama atsakomybė už sukurto produkto gyvavimą: „mes - ne ministerija, mes negalim sakyti, kad štai mes čia sukūrèm labai gerai ir jūs privalot tai naudoti. Mes parodom - yra va taip. Norit - naudojat" (36-IT-D).

Kitų e. sveikatos dalyvių požiūriu, IT atlieka vienintelị vaidmenị - realizuoja jų poreikius: „taigi konkursas... Tas, kas laimes, tas ir padarys, ka mums reikia" (8-L-A). Kai kurie respondentai, pavyzdžiui, medicinos personalo atstovai, dažnai net nejaučia sąlyčio taškų su IT firmomis: „ne, negirdejau, kas laimèjo konkursa, nes man tai nelabai aktualu" (7-P-M). Kiti iš kontaktų su IT įmonių atstovais įsimine, kad jie dažnai nesuvokia sveikatos sistemos procesų sudetingumo: „IT firmu problema - jos ateina nežinodamos reikalavimų. Jos nežino, kiek daug ir ivvairiu duomenu reikia teikti sveikatos srityje. Mes papasakojam, ko reikia, bet jos ateina nesusipažinę, kokie reikalavimai, ka privalu daryti“ (23-L-A). Tačiau daugelis e. sveikatos dalyviu pastebi, kad IT firmos, kaip igyvendintojai, dèl didejjančios konkurencijos vis labiau stengiasi realizuoti užsakovo poreikius: ,jie stengiasi reikalavimus ivykdyti. Tenka juos vykdyti. IT firmos tapo lankstesnés, nes atsirado konkurencija. Tai ir yra variklis" (4-L-IT). Konkurencijos didè- 
jimas, SAM atstovų požiūriu, yra puiki prielaida sustiprinti e. sveikatos produktų kokybę, suteikia užsakovams pasirinkimo laisvès ir nepriklausomumo nuo netinkamo IS kūrèjo, diegejo ir / ar prižiūrètojo. Be to, užtikrinti IS priežiūros ir tobulinimo tęstinumą: „jeigu tas diegèjas neaptarnauja, tai kitas diegejjas gali ta patị daikta aptarnauti. Masès tų diegèjų. Ju skaičius auga atsižvelgiant į mūsų programos didejjimą. Interesas atsirado, tai atèjo ir iš kaimyniniu šalių kompanijos" (32-R-VT).

SPI specialistų vaidmuo. Pagal teorinį vaidmenų pasiskirstymo žinių valdymo ciklų metu modelị SPI specialistams išankstinių, asocijuotų ir naujų žinių etapuose tenka igyvendintojo vaidmuo, nes idejjas reikia paversti realybe. Sutarus dèl sprendimų alternatyvų, jie savarankiškai atlieka užduotis, o sukūrus produktą, jiems tenka stebètojo, ateinančio it pagalbą IS vartotojams, vaidmuo.

Lūkesčiai ir patirtys dèl SPĮ specialistų, o iš jų ypač dèl IT specialistų, vaidmenų jų pačių ir kitų e. sveikatos dalyvių požiūriu, yra įvairios. Jie pripažįstami kaip vieni iš pagrindinių veikejų, lemiančių SPI IS projektų sèkmę: „manau, mūsu pagrindinè sèkmè yra IT komanda, septyni žmonés, jauni entuziastai, kai kurie dirba nuo pat pradžios" (3-L-A). Išorinių IT i̇monių atstovai jais pasitiki kaip specialistais, gebančiais atstovauti užsakovų interesams: „mes stengiamés bendrauti su ìstaigu IT specialistais - kai kurie ir periferijose turi labai kvalifikuotus asmenis ir randam bendra kalbą. Man net lengviau su jais šnekèti, nei su vadovais" (36-IT-D). Kai kurių SPI vadovai IT specialistams patiki koordinatoriaus ir formuotojo vaidmenis: "nuomonè informatiko turi būti svarbiausia. Visi siūlymus pateikia IT skyriaus vadovui. Jis ne tik surenka, bet ir pats po to apibendrina ir siūlo, ka reikia daryti“ (8-L-A). Nepamirštamas ir IT specialistų kaip igyvendintojų vaidmuo: "labai dažnai informatikai ir paskatina su savo idejomis, patys kuria be subrangovu, nes tęstinumui geriau dirbti be jü" (4-L-IT). Respondentai IT specialistai pastebi savo vaidmenų kaitą. Anksčiau iš jų buvo tikimasi tik savarankiškai kurti, prižiūrèti sistemas, tačiau šiuo metu jie papildo ir remia savo žiniomis kitų e. sveikatos dalyvių, ypač medicinos personalo, poreikius. Kaip ir teorinis modelis numato, SPI specialistų stebètojo vaidmuo labai reikšmingas SPI administracijos ir medicinos darbuotojams. Respondentai dažnai minejo, kad "pamoko, padeda, kaip naudotis" (1-P-A), „jeigu stringa, ateina ir pamoko. Pats eini pas juos ir mokaisi“" (7-P-M).

Medicinos personalo ir pacientų vaidmuo. Skirtinguose žinių vadybos etapuose medicinos personalui pagal teorinị modelị tenka skirtingi vaidmenys. Jie atlieka specialistų vaidmenị pirmajame (išankstinių žinių) ir paskutiniame (rezultato žinių) etapuose. Proceso pradžioje jie geriausiai žino, kokia informacija turi būti kuriamoje IS, o pabaigoje jie tampa šios skaitmeninès informacijos pagrindiniais kūrẻjais ir IS vartotojais. Asocijuotų ir sutarimo žinių etapuose medicinos personalas atlieka formuotojo vaidmeni, dalindamasis ir derindamas ìvairių medicinos specialistų žinias. Naujų žinių etape gydytojai ir slaugytojai 
tampa koordinatoriais, nes turi nuspręsti, kas žinių gausoje geriausiai atitinka jų poreikius.

Kalbėdami apie medicinos personalo vaidmenị kai kurie respondentai iškèle problemą, kuriam pagrindiniam e. sveikatos veikejui ši sistema kuriama, t. y. kas pagrindinis naudos gavejjas - medicinos personalas ar pacientai. Kol nacionaliniu lygmeniu neišspręstas šis klausimas, medicinos personalui IS iki šiol nepalengvina darbo (jei nenuspręsta, kad medicinos personalas - pagrindinis vartotojas), o pacientai nepakankamai įtraukiami į sistemų kūrimo procesą ir / ar jų kokybès vertinimą (jei nenuspręsta, kad sistemos kuriamos pacientams). Bet kuriuo atveju respondentai neakcentuoja pacientu vaidmens, o tik mini kaip stebetojus: „pacientai nedalyvauja niekur, o ju ir nereikia - mes žinom, ko jiems reikia" (23-L-A). Kaip rodo Lietuvoje atliktų tyrimų rezulta$\operatorname{tai}^{18}$, vartotojų (ir pacientų, ir medicinos personalo) įtraukimas ị e. sveikatos paslaugų kūrimą dar pakankamai problemiškas: kuriant e. sveikatos sistemas dalyvauja tik 2,6 proc. gyventojų ir 7 proc. medicinos personalo, o tik 2 proc. besinaudojančiu e. sveikatos paslaugomis gyventojų aktyviai prisideda prie e. sveikatos kūrimo teikdami siūlymus dèl jos tobulinimo. Tačiau negalima vienareikšmiškai teigti, kad būtina kuo daugiau pacientų įtraukti ị visus e. sveikatos kūrimo ir diegimo žingsnius, nes kai kuriuose iš jų jie gali ir neturèti žinių, kurių tikimasi. Svarbiausia, kad būtų atsižvelgta ị pacientų kaip būsimų vartotojų poreikius bent atitinkamo modulio kūrimo pradžioje ir būtų vertinama jų nuomonè dèl e. sveikatos paslaugų kokybès. Be to, bendras Lietuvos gyventojų ir asocijuotų pacientų organizacijų socialinio aktyvumo lygis, dažniausiai sveikatos paslaugas gaunančių pacientų kompiuterinio raštingumo lygis, e. sveikatos sistemos naujumas, e. paslaugų pasiekiamumo aprejptis ir kt. veiksniai gali apsunkinti pacientų įtraukties procesą. Vis dèlto paminètina, kad kai kurios SPI randa aktyvių pacientų ir juos įtraukia į ankstesnius e. sveikatos IS kūrimo etapus, o ne tik ị jau įdiegtų IS vertinimus. Tuo tarpu kai kurios SPI atlieka pacientu apklausas, vertindamos jų pasitenkinimą sistemomis: „mes darom gi apklausas. Mes, pavyzdžiui, ir dabar 500 pacientu anketas surinkom" (5-P-A).

Interviu rezultatai rodo, kad medicinos personalas atlieka labai svarbų vaidmeni, bet kartu ši e. sveikatos dalyvių grupe - viena iš problemiškiausių. Jautriausia vieta - kaip įtraukti gydytojus ị IS kūrimą, kartu netrukdant jiems atlikti pagrindinių darbų: „kuriant sistemas reikia suprasti, ka gydytojai turi veikti - gydyti ar užsiimti pašaliniais darbais. <...> Gydytojas neturi atitrūkti nuo paciento" (30-L-M). Tačiau neretai medicinos personalas yra mažai motyvuotas dalyvauti kuriant ir diegiant IS, nes šie ilgai besitęsiantys sudètingi procesai atitraukia nuo darbo su pacientais: „gydytoju požiūris yra toks, kad e. sveikatos prie-

18 Jankauskienè, D., et al. Sveikatos priežiūros darbuotojų ir gyventojų ịtraukimo bei dalyvavimo e. sveikatos sistemoje mastas ir tendencijos Lietuvoje. Mokslo studija. Vilnius: Mykolo Romerio universitetas, 2014. 
monés turi pagerinti gydytoju darba, bet ne daryti ji dar sudètingesnį. Pastoviai besitęsiantys diegimo procesai ir tobulinimai, neužtikrintas jau įdiegtu programu veikimas, vargina ir erzina personala" (28-L-M). Siekdama sušvelninti tokias situacijas SPI administracija stengiasi iš anksto informuoti darbuotojus ir pasiekti, kad medicinos personalas atliktų bent jau stebėtojo ir vertintojo vaidmenis, kol programos bus paruoštos naudoti ir gydytojai bei slaugytojai taps savarankiškai dirbančiais specialistais: „kiekvienq kartą, kai diegi kažka tai naujo, visada padarai susirinkima, padarai mokymus, išaiškini, po to individualiai su jais dirbi. Juk reikia ịtikinti žmogų, norint, kad jis pradètu dirbti“ (8-L-A). Tačiau kai kurios SPI nepalieka medicinos personalo nuošalyje, ir, suvokdamos jo kaip formuotojo vaidmens svarbą, stengiasi ịvairiais būdais aktyvinti medicinos darbuotojų i(si)traukimą nuo IS kūrimo pradžios, išgirsti ir realizuoti jų poreikius: „klausia mūsu nuomonès. Aš netgi buvau tam komitete, kuris buvo sudarytas iš visu specialybiu gydytoju. Teikème pasiūlymus, ko mes norim, ir pagal tai ir buvo kuriama ta sistema" (30-L-M).

Deja, interviu metu neretai išsakyti SPI vadovų ir IT specialistų požiūriai, kad medicinos personalas atlieka tik vartotojo vaidmeni, o ankstesniuose e. sveikatos kūrimo procesuose retai kada atlieka teoriniame modelyje numatytus koordinatoriaus ir formuotojo vaidmenis: „taip kad padiskutuoti su kolektyvu galima tiktai mokymo procese, kai reikia realizuoti, išmokyti naudotis kažkokiais tais konkrečiam gydytojui naudingais, reikalingais funkcionalumais" (25-L-A). Kita vertus, kai kuriais atvejais SPI specialistai, prisiimdami pastaruosius vaidmenis sau, nemato didelio poreikio medicinos darbuotojų integruoti ị sistemų kūrimą, o tik jas pradejus naudoti atlieka specialisto vaidmenị ir padeda jiems spręsti iškylančias technines problemas: „daktarai savo reikalais užsièmę, jie nori kuo mažiau gilintis. Mums taip paprasčiau... Kai būna koks nors nesklandumas, tada ir klausinejam" (6-P-IT).

Tos SPĮ, kurios susiduria su aštriausia medicinos personalo atotrūkio nuo e. sveikatos kūrimo problema, kaip pagrindinę priežastị ịvardina žemą gydytojų motyvacijos lygị: „mažai tokių gydytojų, kurie domisi sistemos tobulinimu. Vienas gydytojas rašé už visus" (18-L-IT). Šios priežasties nepaneigia ir patys medicinos personalo atstovai: „aš jums prisipažinsiu, kad kitose įstaigose aš neturiu nei kompiuterio, nei laiko, kad galèčiau gilintis i visus mygtukus. Man labiau sistema trukdo. Aš neturiu jai laiko" (57-Pr-M). Vis dèlto interviu metu pastebéta, kad reta kuri SPI neranda bent vieno gydytojo ir / ar slaugytojo, kuris būtų besidomintis IS ir aktyviai dalyvautų visuose e. sveikatos sistemų kūrimo, diegimo ir palaikymo procesuose kartu atlikdamas medicinos personalo interesu ir poreikių patenkinimo atstovavimo vaidmenị. Be to, didejant gydytojų ir slaugytojų kompiuteriniam raštingumui, stebimi teigiami pokyčiai aktyvinant šių e. sveikatos sistemos dalyvių vaidmenis. 


\section{Išvados}

Tyrimas parode, kad teorinis vaidmenu pasiskirstymo modelis tik iš dalies yra realizuojamas praktikoje. Atrodo, kad SAM vykdo per daug funkcijų ir per mažai jų tenka pačiai SPİ. Tai iš dalies galima paaiškinti e. sveikatos naujumu ir pirmojo šios sistemos etapo klaidų ịvertinimu, kai e. sveikatos sistemos kūrimo procesams trūko ministerijos vadovavimo ir koordinavimo. Vis delto šiuo metu pasigendama ryškesnio SPĮ lyderiavimo prisiimant formuotojo funkcijas. Taip pat beveik visiškai yra ignoruojamas pacientas. Jo vaidmuo daugiau teorinis, žinant, kad jie lyg ir reikalingi produktui kurti, bet praktiškai pastangų nededama tai realizuoti. Interviu rezultatai rodo požiūrio i̇ ịvairius e. sveikatos dalyvius ir jų vaidmenis pokyčius. Vis labiau atsižvelgiama i poreikị tarpusavyje keistis žiniomis ir patirtimis, atsižvelgti i̇ vieni kitų poreikius ir lūkesčius. Tačiau ne visada apsispręsta, kas iš e. sveikatos dalyvių - medicinos personalas ar pacientai - yra galutiniai vartotojai ir turi gauti didžiausią naudą. Dèl to gali būti, kad patys svarbiausi veikẻjai per mažai ịtraukiami ị e. sveikatos IS kūrimo ir diegimo procesus, o tai gali lemti, kad nebus ịdiegti svarbūs elementai.

Stebima tendencija, kad nepriklausomai nuo žinių ciklo etapo e. sveikatos dalyviai kiekviename etape pageidautų stipraus koordinatoriaus. Jie šias funkcijas linkę perleisti Sveikatos apsaugos ministerijai, taip tikèdamiesi perduoti ir atsakomybę dèl sprendimų apie finansus bei galutinio rezultato kokybės. Tačiau moksliniai vaidmenų ir funkcijų pasiskirstymo tyrimai rodo, kad reiškiantis stipriam koordinatoriui, atliekamų veiksmų kokybė turi tendenciją nukentėti. O tai dažniausiai ịvyksta dèl sumažèjusio darbo grupès kūrybiškumo, dèl iniciatyvos slopinimo. Tuo tarpu koordinatoriaus vaidmeni peremus specialistams (SPI specialistams ar medicinos personalui), galima būtų sukurti vartotojui draugiškesnị, vadinasi, ir priimtinesnį, e. sveikatos produktą, kuris geriau atitiktų poreikius tų, kurie jais naudosis ateityje.

Perdavus lyderio vaidmenį SPIt, funkcijų paskirstymo problemos nebūtų visiškai išspręstos dẻl IT įmonių, kaip produkto kūrèjo, indèlio sureikšminimo arba kito kraštutinumo - ignoravimo ir izoliavimo. Tad IT i̇monių, kaip formuotojo, vaidmuo galimas tik vienoje iš žinių valdymo fazeje, o kitose fazėse jų indèlis dalinamas tarp igyvendintojo ir stebètojo.

Teigiama tendencija, kad Sveikatos apsaugos ministerija nekovoja dèl universalaus koordinatoriaus vaidmens. Atvirkščiai - patys inicijuoja kūrybiškumo ir inovatyvumo paieškas perduodami iniciatyvos, o kartu ir atsakomybès, teisę SPI.

Padeka. Straipsnis parengtas pagal mokslinio tyrimo, finansuojamo Europos socialinio fondo léšomis pagal visuotines dotacijos priemonę, medžiaga (projektas „E. sveikatos pletros integruotos transformacijos: suinteresuotuju pusiu tinklo perspektyva“, projekto kodas VP1-3.1-ŠMM-07-K-02-029). 


\title{
Literatūra
}

1. Bales, R. F. A set of categories for the analysis of small group interaction. American Sociological Review. 1950, 15: 257-263.

2. Belbin, R. M. Management Teams: Why They Succeed or Fail. Oxford: ButterworthHeinemann, 1981.

3. Belbin, R. M. Team Roles at Work. Oxford: Butterworth-Heinemann.

4. Benne, K. D.; Sheats, P. 1948. Functional roles of group members. Journal of Social Issues. 1993, 4: 41-49.

5. Chong, E. Role Balance and Team Development: A Study of Team Role Characteristics Underlying High and Low Performing Teams. Journal of Behavioral and Applied Management. 2007, May 1.

6. Hackman, J. R.; Wageman, R.; Ruddy, T. M.; Ray, C. R. Team effectiveness in theory and practice. In: Cooper, C. and Locke, E. A. Industrial and organizational psychology: Theory and practice. Oxford, UK: Blackwell, 2000.

7. Jankauskienè, D., et al. Sveikatos priežiūros darbuotojų ir gyventoju ịtraukimo bei dalyvavimo e. sveikatos sistemoje mastas ir tendencijos Lietuvoje. Mokslo studija. Vilnius: Mykolo Romerio universitetas, 2014.

8. King, G., et al. Boundaries and e-health implementation in health and social care. BMC Medical Informatics and Decision Making [interaktyvus]. 2012,12(100): 1-11]. [žiūrèta 2014-08-10]. <http://www.biomedcentral.com/1472-6947/12/100>.

9. McFadzean, E. Developing and supporting creative problem-solving teams: Part $1-\mathrm{a}$ conceptual model. Management Decision. 2002, 40(5/6): 463-476.

10. Nonaka, I.; Nishiguchi, T. Knowledge Emergence. Social, Technical, and Evolutionary Dimensions of Knowledge Creation. Oxford University Press, New York, 2001.

11. Partington, D.; Harris, H. Team balance and team performance: an empirical study. The Journal of Management Development. 1999,18(8): 694-701.

12. Prager, K.; Nagel, U. J. Participatory decision making on agri-environmental programmes: a case study from Sachsen-Anhalt (Germany). Land Use Policy. 2008, 25: 106-115.

13. Senior, B. Team roles and team performance: Is there 'really' a link? Journal of Occupational and Organizational Psychology. 1997, 70(3)): 241-258.

14. WHO-ITU. 2012. National eHealth Strategy Toolkit [interaktyvus]. [žiūrèta 201408-10]. <http://www.searo.who.int/entity/health_situation_trends/documents/full_ version_national_ehealth_toolkit.pdf>.

\section{The Importance of Distribution of Functions for E-health Actors: A Set of Stakeholders' Roles}

\author{
Birutė Mikulskienė, Birutė Pitrènaitè-Žilènienė, Danguolè Jankauskienė \\ Mykolas Romeris University, Lithuania
}

Summary. The objective of the present research is to develop a model for cooperation and distribution of e-health interested functions and to test the model in an actual health care system, i.e., to check how Lithuania's e-health interested 
partiesshare theircooperative roles and functions in the multidisciplinary knowledge control cycle to develop elements of the e-health system. The aforementioned model is based on the key assumption that a health care institution and its employees are major users and owners of e-health production and therefore take the leading role. Two management theories have been employed: the knowledge control process and the theory of role distribution in the cooperation cycle. The core of the theoretical model is to tackle the question as to which of the interested parties and during which knowledge generation phases should take coordinating, developing, observing, implementing and specialist roles.

The practical testing of the model has revealed that the theoretical role distribution model is only partly realized in practice. The Ministry of Health Care performs excessive functions leaving too few for health care institutions. Patient participation is also ignored. Moreover, a tendency that e-health participants constantly request a strong coordinator independently of the stage of the knowledge cycle has been observed. The participants tend to pass the function on to the Ministry of Health Care in expectation to simultaneously dispose responsibility for financial decisions and the quality of final results. Having passed the leading role on to the health care institution, the problems of distribution of functions would remain incompletely resolved due to an overestimated contribution of IT companies as product developers or other reasons, including disregard and isolation. Thus, the developing role of IT companies is possible only in a separate knowledge control phase, whereas their contribution during other phases is shared between an implementor and observer.

Keywords: $e$-health, stakeholders, knowledge management, role theory.

Birutè Mikulskienė, Mykolo Romerio universiteto Politikos ir vadybos fakulteto Vadybos instituto profesorè, fizinių mokslų daktarè. Mokslinių tyrimų kryptys: sprendimų priemimas, suinteresuotųjų vadyba, e. sveikata.

Birutè Mikulskienè, Doctor of Physical Sciences, Mykolas Romeris University, Faculty of Politics and Management, Institute of Management, Professor. Research interests: decision-making, e-health, stakeholder management.

Birutė Pitrẻnaitė-Žilẻnienė, Mykolo Romerio universiteto Politikos ir vadybos fakulteto Vadybos instituto profesorè, socialinių mokslų daktarè. Mokslinių tyrimų kryptys: viešasis saugumas, e. sveikata, suinteresuotųjų vadyba, socialinès technologijos viešajam valdymui.

Birutė Pitrẻnaitė-Žilènienė, Doctor of Social Sciences, Mykolas Romeris University, Faculty of Politics and Management, Institute of Management, Professor. Research interests: public safety, e-health, stakeholder management, social technologies in public sector. 
Danguolė Jankauskienė, Mykolo Romerio universiteto Politikos mokslų instituto profesoré, biomedicinos mokslų daktarè. Mokslinių tyrimų kryptys: sveikatos politika, sveikatos sistemos administravimas ir veiklos valdymas, e. sveikata.

Danguolé Jankauskiené, Doctor of Biomedicine and Social Sciences, Mykolas Romeris University, Institute of Political Sciences, Professor. Research interests: health policy, health system governance, e-health. 